\title{
Cervical Cell Classification using Learning Vector Quantization (LVQ) Based on Shape and Statistical Features
}

\author{
https://doi.org/10.3991/ijoe.v15i02.9796 \\ Erlinda Metta Dewi, Endah Purwanti ${ }^{(凶)}$, Retna Apsari \\ Airlangga University, Surabaya, Indonesia \\ endah-p-1@fst.unair.ac.id
}

\begin{abstract}
This research was conducted to design a system that is able to classify cervical cells into two classes, namely normal cells or abnormal cells. We use digital images of single cervical as research materials and Learning Vector Quantization (LVQ) as classification method. Prior to classification, the nucleus areas of single cervical cell images were segmented and features were extracted. The features used in this study are 7 kinds of which consist of 2 types of feature, namely shape features and statistical features. The shape features used are area, perimeter, shape factor, and roundness of the nucleus, while the statistical features of the grayscale image histogram used are mean, standard deviation, and entropy. LVQ optimal parameter values based on the highest accuracy of training data, are learning rate 0.1 and learning rate reduction 0.5 . The highest accuracy of system obtained from 45 testing data is $93.33 \%$.
\end{abstract}

Keywords - Single cervical cell image, cervical cell classification, features extraction, Learning Vector Quantization.

\section{Introduction}

Cervical cancer ranks as the second most common type of cancer affecting women around the world and $80 \%$ of death cases come from developing countries [1]. Unlike other cancers, cervical cancer can be prevented with proper treatment when the cells are still in the precancerous stage, it is the stage where the abnormal cervical cells already detected but still have not reached the cancerous stage [2].

One method for the early detection of cervical cancer is by using pap smear test. This test is a method of visual inspection of the cervical cells under a microscope to detect any abnormal cells that could potentially develop into cancer cells. Diagnosis of pap smear test results have high false rate ranged between 5\% -50\% [3]. Because the inspection is done manually, the examination of cervical cells susceptible to misinterpretation. One effort to reduce the number of errors is by automatically classification based on artificial neural network (ANN) algorithms that have reliable ability to recognize data patterns. Attempts to classify a single cervical cell have been conducted by several researchers. Norup extract 20 kinds of shape features from a single cervical cell that 
can be used as classification's input [4]. Agustina use the ratio of the nucleus to the cytoplasm and produces an accuracy of $78 \%$ for abnormal cells image [5]. Meutia use the image intensity values from segmented cervical cell image to classify cervical cells using Learning Vector Quantization (LVQ) method which produces an accuracy of $82 \%$ [6]. LVQ is one of the ANN models which has a fairly simple architecture but has good performance as a classification engine.

This study seeks to combine the best features of previous research studies. There are 4 features of the form taken, including the area, perimeter, roundness and nucleus form factor. In addition we also propose 3 features of histogram, namely the mean, standard deviation and entropy with the aim of obtaining cervical cell texture. According to Hoda, the worse the abnormal condition of cervical cells, the cell nucleus will appear increasingly irregular and there is granulation [7]. So that the overall features used in this study are 7 features. For classification machines, we use LVQ as one of the supervised neural network models that are reliable in speed and accuracy of data pattern recognition.

\section{Materials and Methods}

\subsection{Data preparation}

Digital image data of single cervical cell used in this study were obtained from the database built by Department of Pathology, Herlev University Hospital, Denmark. Each image was visually inspected (manually) and classified into normal cells and abnormal cells by 2 cytologists and a doctor. The entire images are in bitmap (*.bmp) with a resolution of 0.201 micrometer/pixel. The number of images used as many as 65 data for normal cells (50 data for LVQ training and 15 data for LVQ testing) and 130 data for abnormal cells (100 data for LVQ training and 30 data for LVQ testing).

\subsection{Program design}

The design of the program consists of nucleus segmentation, shape and statistical features extraction, and classification of a single cervical cell with a artificial neural network, as shown in Figure 1.

Before it can be classified into normal cells or abnormal cells, a digital image of single cervical cell must pass through a series of processes in advance to obtain the results of shape and statistical features values that will be used for classification's input using LVQ method. These processes begin with a series of grayscaling, digital image processing, and nucleus segmentation to obtain the values of shape features. As for the statistical feature, the values were obtained from a grayscale image histogram of cervical cell. 


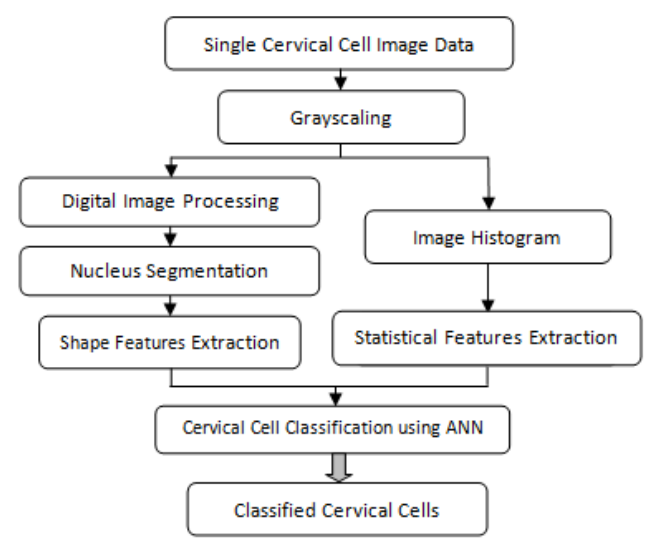

Fig. 1. Flowchart of program design

\subsection{Digital image processing}

Digital images of a single cervical cell changed from a color image into a grayscale image that has only one color component with the intensity range from 0 to 255 . Image preprocessing method of median filtering and contrast stretching were used to improve the image quality before further processing. Filtering is a method of improving the image quality and is used to reduce noise [8]. Median filtering is a filtering technique that uses the median values of the kernel matrix as a new pixel value at the center of the kernel. This technique is better than the mean filtering in terms of preserving the sharpness of image edges. Contrast stretching is a technique to improve image contrast by stretching the image field with remapped pixel intensities in the new range. Image contrast stretching results are then processed by morphological processing operations such as opening and closing to reduce the small areas that appear light or dark (small bright or dark regions) that can interfere with the process of nucleus segmentation. Morphological processing is an operation on the image to produce a binary modified image. Morphological processing basically consists of two basic operations, namely dilation and erosion [9]. Opening is a process that consists of erosion operation followed by a dilation operation with the same SE (structuring element). Conversely, closing is a process that consists of dilation operation followed by erosion operation with the same SE.

\section{$2.4 \quad$ Nucleus segmentation}

Thresholding is the selection of a threshold value $(\mathrm{T})$ in which the pixels are valued below the threshold value will be set to black and the pixels are valued above the threshold value will be set to white. Nucleus segmentation is done by using a thresholding level value of 0.2 (for the intensity range 0 to 1 ). Binary image after thresholding then reprocessed with clearing operation of morphological processing to remove other objects related to the image border instead of the target image segmentation. The final result of segmentation is a binary image of the cervical cell nucleus. 


\subsection{Features extraction}

Types of features used in this study are shape features and statistical features. Shape features obtained from the binary image of the nucleus, while the statistical features obtained from a grayscale image histogram. The features used are as follows:

\section{Shape Features [10]:}

- Nucleus area: scalar value that states the total number of the nucleus pixels.

- Nucleus perimeter: scalar value that states the number of nucleus outline pixels.

Nucleus shape factor: scalar value which is defined in equation 1.

$$
\mathrm{S}_{\text {Nucleus }}=\frac{\text { Nucleus perimeter }^{2}}{\text { Nucleus area }}
$$

Nucleus roundness: scalar value which is defined in equation 2.

$$
\mathrm{R}_{\text {sitoplasma }}=\frac{4 \times \pi \times \text { Nukleus area }}{\text { Nucleus perimeter }}
$$

Statistical Features [7]:

Mean: scalar value which is defined in equation 3 .

$$
\mathrm{m}=\sum_{\mathrm{i}=0}^{\mathrm{L}-1} \mathrm{i} \mathrm{p}(\mathrm{i})
$$

Standard deviation: scalar value which is defined in equation 4 .

$$
\sigma=\sqrt{\sum_{\mathrm{i}=0}^{\mathrm{L}-1}(\mathrm{i}-\mathrm{m})^{2} \mathrm{p}(\mathrm{i})}
$$

Entropy: scalar value which is defined in equation 5 .

$$
\mathrm{e}=-\sum_{\mathrm{i}=0}^{\mathrm{L}-1} \mathrm{p}(\mathrm{i}) \log _{2} \mathrm{p}(\mathrm{i})
$$

\subsection{LVQ Training}

Features extraction values will be used as the input data for ANN. LVQ is the ANN method that is used for the classification of cervical cells are. LVQ implementation includes two terms, the data training and the data testing. Cervical cell images will be classified into groups of normal cells and abnormal cells.

LVQ training using 150 image data comprising 50 normal cell data and 100 abnormal cell data. All data is performed image processing and nucleus segmentation, and then 7 kinds of features are extracted from the image. These features are organized into 
feature datasets in a $150 \times 7$ matrix size and used as input data for the ANN training process.

Initial weights used are the features values of image data for each of the target classification, i.e. normal cells (the target was given a value of 1) and abnormal cells (the target was given a value of 2). LVQ parameters that are varied for system training needs are the learning rate $(\alpha)$ of $0.1 ; 0.01$ and 0.001 . Whereas the reduction in learning rate $(\operatorname{dec} \alpha)$ varied as follows: $0.01,0.1 ; 0.25$ and 0.5 .

\section{$3 \quad$ Result and Discussion}

A total of 195 digital image data is passing through a series processes consist of image processing, nucleus segmentation, and feature extraction. The data is divided into two groups, there are 150 training data and 45 testing data for LVQ implementation. Each group of data includes 2 target class, the normal cells and the abnormal cells. The testing data is used in the validation test that aims to determine the accuracy of the program that has been created.

\subsection{Nucleus segmentation result}

Having gone through the processes of image processing, starting from median filtering, contrast stretching, and morphological processing such as opening and closing operation, the nucleus from the image is then segmented. Nucleus segmentation is done by using thresholding method with a value of 0.2 . The nucleus binary image result from thresholding still leaves other objects at the image border that are not part of the nucleus. A clearing operation from morphological processing method is used to remove that objects, as shown in Figure 2.

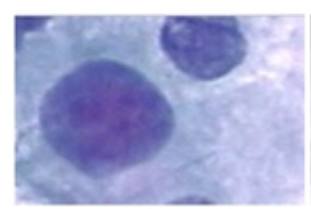

(a)

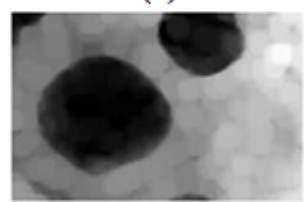

(e)

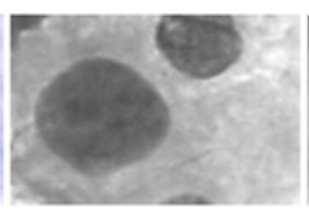

(b)

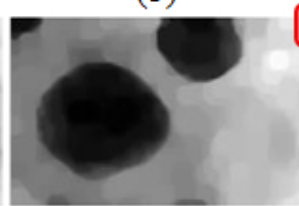

(f)

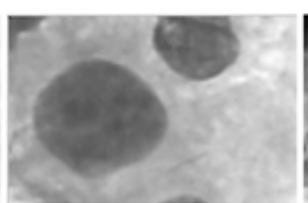

(c)

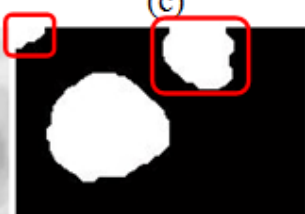

(g)

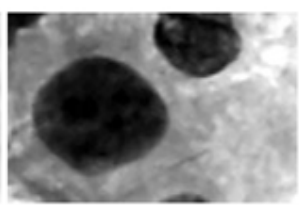

(d)

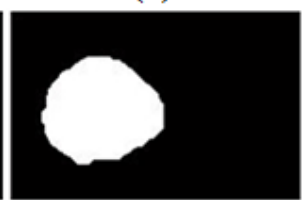

(h)

Fig. 2. Nucleus segmentation processes (a) original image

(b) grayscale image (c) median filtering (d) contrast stretching (e) opening

(f) opening and closing (g) thresholding (h) clearing 


\subsection{Features extraction result}

From the features extraction results, there are 2 features which are the most powerful features, the nucleus area and the nucleus perimeter. It because these features have quite a big difference and not many overlapping values between normal cells and abnormal cells. While the other 5 features, which are nucleus shape factor and roundness, mean, standard deviation, and entropy, even though it can be used as features for classification of cervical cells, but these features are still classified as a weak feature due to the difference values is significantly thinner and more values are overlapping between the normal cells and abnormal cells.

\subsection{LVQ training result}

LVQ training is done with the parameter values and some variations in the value of learning rate $(\alpha)$ and learning rate reduction $(\operatorname{dec} \alpha)$ as given in Table 1. After the LVQ training process is complete, the final weights obtained will be used for testing back the training image data that have previously been trained. The testing back is done to determine the optimal parameter values of $\alpha$ and dec $\alpha$ to be used to classify cervical cells. The accuracy of training data based on the variation of parameter values $\alpha$ and $\operatorname{dec} \alpha$ is shown in Table 1.

Table 1. Table with the training data accuracy variation of $\alpha$ and dec $\alpha$

\begin{tabular}{|c|c|c|}
\hline $\boldsymbol{\alpha}$ & Dec $\boldsymbol{\alpha}$ & Accuracy \\
\hline \multirow{4}{*}{0.1} & 0.01 & $83.33 \%$ \\
\cline { 2 - 3 } & 0.1 & $84 \%$ \\
\cline { 2 - 3 } & 0.25 & $84.67 \%$ \\
\cline { 2 - 3 } & 0.5 & $88.67 \%$ \\
\hline \multirow{4}{*}{0.01} & 0.01 & $83.33 \%$ \\
\cline { 2 - 3 } & 0.1 & $85.33 \%$ \\
\cline { 2 - 3 } & 0.25 & $86.67 \%$ \\
\hline \multirow{4}{*}{0.001} & 0.5 & $71.33 \%$ \\
\cline { 2 - 3 } & 0.01 & $85.33 \%$ \\
\cline { 2 - 3 } & 0.1 & $45.30 \%$ \\
\cline { 2 - 3 } & 0.25 & $40.30 \%$ \\
\hline
\end{tabular}

From Table 1, the highest value of the training data accuracy is $88.67 \%$. This accuracy obtained by using the parameter values $\alpha$ of 0.1 and dec $\alpha$ of 0.5 . The value of $\alpha$ and dec $\alpha$ is the optimal parameter values for the classification of cervical cells. Henceforth, the final weights obtained after LVQ training with these parameter values will be saved and used for the testing of testing image data to obtain the optimal accuracy of cervical cells classification system.

\subsection{LVQ testing result}

In LVQ testing, the image data used as many as 45 image data consist of 15 normal cell image data and 30 abnormal cell image data. The testing process is done based on 
the final weights obtained after LVQ training with optimal parameter values $\alpha$ of 0.1 and dec $\alpha$ of 0.5 . Testing data classification is done based on the proximity distance (D) between the value of testing data features and the final weights obtained from LVQ training. If the distance between the value of testing data features and the first final weights (normal cell class) is smaller then the data will be classified into normal cells, to the contrary, if the distance between the value of testing data features and the second final weights (abnormal cell class) is smaller then the data will be classified into the abnormal cells.

To determine the optimal accuracy of cervical cell classification system, the results of testing data classification based on LVQ are compared with the target of classification which is the classification done by cytologists and doctor. The accuracy rate from testing data classification is shown in Table 2.

Table 2. Table of accuracy rate from testing data classification

\begin{tabular}{|l|c|c|c|c|}
\hline Class & Amount & Match & Not Match & Accuracy \\
\hline Normal cell & 15 & 15 & 0 & $100 \%$ \\
\hline Abnormal cell & 30 & 27 & 3 & $90 \%$ \\
\hline Total & 45 & 42 & 3 & $93.33 \%$ \\
\hline
\end{tabular}

From the results of 45 testing data, 42 data are match and 3 data are not match. This results provide optimal accuracy of cervical cells classification system by $93.33 \%$. If the accuracy is separated between normal and abnormal classes, the accuracy of normal class is $100 \%$ and the accuracy of abnormal class is $90 \%$.

The highest accuracy rate of $93.33 \%$ is better than the previous study [6], which results an accuracy rate of $82 \%$ with the same ANN network (LVQ method) and the same case of classification, which is the classification of a single cervical cell into normal and abnormal classes.

\section{Conclusion}

This study has succeeded in identifying the digital image of a single cervical cell into 2 classes, namely the normal class and the abnormal class. The scenario of network parameter variations shows that the optimal LVQ parameter has been obtained, namely learning rate 0.1 and reduction in learning rate 0.5 . The selection of the 7 best features of cervical cell images is also able to support the performance of the classification engine so that it can recognize 45 test data with the highest accuracy of $93.33 \%$.

\section{$5 \quad$ References}

[1] WHO. 2002. Cervical Cancer Screening in Developing Countries. ISBN 92-4-154572-0, Geneva.

[2] Muharam, R., Indarti, J., Soepardiman, H.M. 2000. Akurasi Diagnostik Sitologi pada Lesi Prakanker Serviks di Bagian Obstetri dan Ginekologi Fakultas Kedokteran Universitas Indonesia - RS Dr. Cipto Mangunkusumo. Universitas Indonesia. Jakarta. 
Short Paper - Cervical Cell Classification using Learning Vector Quantization (LVQ)...

[3] Suwiyoga, I Ketut. 2004. Beberapa Masalah Pap Smear sebagai Alat Diagnosis Dini Karakter Serviks di Indonesia. Laboratorium Obstetri dan Ginekologi Fakultas Kedokteran Universitas Udayana. Denpasar.

[4] Norup, Jonas. 2005. Classification of Pap Smear Data by Transductive Neuro- Fuzzy Methods. University of Denmark.

[5] Agustina, Silvia. 2008. Analysis of Pap Smear Image Using Computer Software. Faculty of Life Science, Biomedical Engineering, Swiss Germany University (SGU).

[6] Meutia, Syarifah Dina. 2009. Segmentasi Citra Sel Serviks Menggunakan Algoritma Multifraktal dengan Adaptive Multiple Thresholding dan Klasifikasi Menggunakan Learning Vector Quantization. Fakultas Ilmu Komputer, Program Studi Ilmu Komputer, Universitas Indonesia.

[7] Hoda, Rana S., Hoda, Syed. A., 2007, Fundamental of Pap Test Cytology,Humana Press, Totowa, New Jersey.

[8] Gonzalez, R.C., Woods, Richard E. 2002. Digital Image Processing. Pearson Education, Inc: New Jersey.

[9] Solomon, C., Breckon, T. 2011. Fundamental of Digital Image Processing: A Practical Approach with Examples in Matlab. John Willey \& Sons, Ltd: United Kingdom.

[10] Ahmad, Usman. 2005. Pengolahan Citra Digital \& Teknik Pemrogramannya. Penerbit Graha Ilmu: Yogyakarta.

[11] Putra, Darma. 2009. Pengolahan Citra Digital. Penerbit Andi: Yogyakarta.

\section{Authors}

Erlinda Metta Dewi is with the Faculty of Science and Technology at Airlangga University.

Retna Apsari is a professor in the Faculty of Sciences and Technology. She has conducted studies in the field of bio-optics and laser application.

Article submitted 31 October 2018. Final acceptance 14 December 2018. Final version published as submitted by the authors. 